\title{
Penerapan Metode Bayes dalam Menentukan Model Estimasi Reliabilitas Pompa Submersible pada Rumah Pompa Wendit I PDAM Kota Malang
}

\author{
Widya Arrya Septiana dan Soehardjoepri \\ Departemen Matematika, Fakultas Matematka dan Ilmu Pengetahuan Alam, Institut Teknologi Sepuluh Nopember \\ (ITS) \\ e-mail: djoepri.its@gmail.com
}

\begin{abstract}
Abstrak-Pemeliharaan sistem dan peralatan-peralatan dalam suatu perusahaan merupakan salah satu faktor penting dalam mendukung produktivitas dan kualitas produk yang baik. Pemeliharaan peralatan produksi dengan melakukan kontrol keandalan (reliabilitas) dapat mengurangi gangguan pada sistem produksi sehingga mampu mengoptimalkan pendapatan keuntungan bagi perusahaan. PDAM (Perusahaan Daerah Air Minum) Kota Malang, selaku penyedia layanan air bersih sering kali menemui kendala dalam proses produksi air akibat kerusakan pada pompa submersible, sehingga mengalami kerugian yang cukup besar. Sebagai upaya mengurangi kerugian dengan mencegah kerusakan pompa submersible, PDAM Kota Malang perlu untuk mengetahui nilai reliabilitas pompa untuk menjadwalkan waktu pemeliharaan dengan tepat. Penelitian ini dilakukan untuk mendapatkan nilai reliabilitas dari model estimasi relibilitas dengan metode Bayes menggunakan distribusi terbaik. Data yang digunakan adalah data waktu antar waktu kerusakan pompa submersible pada Rumah Pompa Wendit I PDAM Kota Malang. Model yang diperoleh diterapkan untuk mendapatkan nilai reliabilitas pompa yaitu nilai reliabilitas Pompa I adalah 0.403, Pompa II adalah 0.69464 dan Pompa III adalah 0.7701. Sedangkan nilai reliabilitas untuk sitem perpompaan pada rumah pompa Wendit I PDAM Kota Malang adalah 0.9581 .
\end{abstract}

Kata Kunci-Metode Bayes, Pompa Submersible, Reliabilitas.

\section{PENDAHULUAN}

$\mathrm{P}$ ERUSAHAAN yang bergerak di bidang jasa maupun produksi produk sangat memperhatikan kualitas pelayanan dan kualitas produk untuk memuaskan pelanggan demi mendapat keuntungan yang memungkinkan. [1]. Salah satu faktor yang memiliki potensi besar dalam meningkatkan produktivitas dan profitabilitas yang optimal adalah membentuk manajemen pemeliharaan yang tepat [2]. Pemeliharaan peralatan produksi dengan melakukan kontrol keandalan (reliabilitas) dapat mengurangi gangguan pada sistem produksi sehingga mampu mengoptimalkan pendapatan keuntungan bagi perusahaan [3].

PDAM Kota Malang merupakan salah satu perusahaan milik daerah yang mempunyai peran penting dalam melaksanakan pengelolahan dan memberikan pelayanan air bersih untuk meningkatkan kesajahteraan masyarakat kota Malang. PDAM kota Malang hampir setiap bulan mengalami gangguan pada pompa air baku sehingga mengakibatkan kerugian yang cukup besar. Oleh karena itu, sebelum dilakukan penjadwalan pemeliharaan, PDAM Kota Malang perlu untuk mengetahui nilai reliabilitas dari pompa submersible agar dapat mencegah terjadinya kerugian PDAM akibat kerusakan pompa. Penelitian Tugas Akhir ini dilakukan untuk mengetahui model estimasi reliabilitas guna mendapatkan nilai reliabiltas pompa submersible.

Pada penelitian ini akan didapatkan model estimasi reliabilitas distribusi weibull dan model estimasi reliabilitas distribusi lognormal dengan metode Bayes. Data yang digunakan adalah data waktu antar waktu kerusakan pompa I, pompa II dan pompa III pada rumah pompa Wendit I PDAM Kota Malang dari Januari 2008 hingga Februari 2017. Data tersebut akan diuji kecocokan distribusinya menggunakan Index of Fit dan Goodness of Fit untuk menentukan penggunaan distribusi terbaik dalam mengestimasi reliabilitas pompa submersible air baku. Distribusi yang digunakan dalam menentukan model estimasi reliabilitas dengan metode Bayes dalam penelitian ini adalah distribusi weibull dan distribusi lognormal. Model estimasi reliabilitas yang digunakan dalam mencari nilai reliabilitas pompa submersible pada rumah pompa Wendit I PDAM Kota Malang apada tanggal 15 Maret 2017 sebagai salah satu output dari penelitian Tugas Akhir ini, diharapkan dapat menjadi bahan pertimbangan PDAM Kota Malang dalam menentukan waktu pemeliharaan maupun waktu pergantian pompa submersible PDAM Kota Malang.

\section{DASAR TEORI}

\section{A. Metode Bayes}

Sebuah model statistik Bayes terbentuk dari parameter model statistik $f(t \mid \theta)$ dan distribusi prior $\pi(\theta)$. Secara umum peluang dengan menggunakan teorema Bayes dideskripsikan dengan keadaan jika $A$ dan $E$ adalah kejadian di mana $(E) \neq 0, P(A \mid E)$ dan $P(E \mid A)$ saling berhubungan. Berikut iniadalah peluang terjadi peristiwa $\mathrm{E}$ dengan syarat $\mathrm{A}$ [3]:

$$
P(A \mid E)=\frac{P(E \mid A) P(A)}{P(E)}
$$

\section{B. Fungsi Reliabilitas}

Reliabilitas adalah peluang sebuah komponen atau suatu sistem akan bekerja sesuai fungsinya pada jangka waktu tertentu ketika digunakan dibawah kondisi operasional tertentu [4]. Berdasarkan intensitas kerusakannya, distribusi probabilistik yang digunakan dalam menentukan nilai 
reliabilitas dibagi menjadi dua, yaitu apabila model nilai kerusakan konstan dapat menggunkan distribusi eksponensial sedangkan apabila model nilai kerusakan tidak konstan dapat distribusi weibull, normal dan lognormal.

\section{Distribusi Eksponensial}

Sebuah variabel acak kontinu dikatakan sebagai variabel acak eskponensial dengan parameter $\lambda$ jika fungsi peluang kepadatannya sebagai berikut [4] :

$$
f(t)= \begin{cases}\frac{1}{\lambda} e^{-\frac{\mathrm{t}}{\lambda}} & ; \text { jika } 0<t<\infty \\ 0 & ; \text { t yang lain }\end{cases}
$$

Jika $t$ merupakan waktu kerusakan, maka fungsi keandalannya $(R(t))$ sebagai berikut:

$$
R(t)=e^{-\frac{t}{\lambda}}
$$

\section{Distribusi Weibull}

Jika diberikan parameter bentuk $\theta$ dan parameter lokasi $\beta$ serta $t$ adalah waktu kerusakan maka fungsi padat peluang $(f(t))$ distribusi weibull sebagai berikut :

$$
f(t)=\left\{\begin{array}{l}
\frac{\beta}{\theta} t^{\beta-1} e^{-\frac{t^{\beta}}{\theta}} ; \text { jika } 0<t<\infty \\
0 \quad ; \text { t yang lain }
\end{array}\right.
$$

Jika $t$ merupakan waktu kerusakan, maka fungsi keandalannya $(R(t))$ sebagai berikut:

$$
R(t)=e^{-\left(\frac{t}{\theta}\right)^{\beta}}
$$

\section{Distribusi Lognormal}

Sebuah variabel acak $T$ berdistribusi lognormal dengan rata-rata $\mu$ dan varian $\sigma^{2}$ serta $t$ adalah waktu kerusakan mesin sehingga fungsi padat peluang $(f(t))$ distribusi lognormal sebagai berikut :

$$
f(t)= \begin{cases}\frac{1}{t \sigma \sqrt{2 \pi}} e^{-\frac{1}{2}\left(\frac{\ln (t)-\mu}{\sigma}\right)^{2}} & ; \text { jika } 0<t<\infty \\ 0 & ; t \text { yang lain }\end{cases}
$$

Fungsi reliabiltas distribusi lognormal untuk $t$ merupakan waktu kerusakan sebagai berikut [5]:

$$
R(t)=\phi\left(\frac{\mu-\ln (t)}{\sigma}\right)
$$

Dalam penelitian ini digunakan estimasi Bayes. Estimasi reliabilitas $\left(R(t)^{*}\right)$ dengan metode Bayes pada distribusi tertentu dengan parameter $\theta_{1}$ dan $\theta_{2}$ didefinisikan sebagai [14]

$$
R(t)^{*}=E(R(t) \mid T)=\iint R(t) \pi\left(\theta_{1}, \theta_{2} \mid T\right) d \theta_{1} d \theta_{2}
$$

dengan,

$E(R(t) \mid T)$ : Nilai ekspektasi atas T dengan syarat $R(t)$,

$R(t) \quad$ : Fungsi reliabilitas distribusi peluang tertentu, $\pi\left(\theta_{1}, \theta_{2} \mid T\right)$ : Distribusi posterior parameter $\theta_{1}$ dan $\theta_{2}$.

\section{Fungsi Reliabilitas Sistem Paralel}

Dua atau lebih komponen dalam sistem dikatakan terkonfiguarasi paralel apabila kerja satu komponen tidak mempengaruhi komponen yang lain. Reliabilitas sistem dengan konfigurasi paralel dirumuskan dengan [4]:

$$
R_{s}(t)=1-\prod_{i=1}^{n}\left(1-R_{i}(t)\right) ; 0<i \leq n
$$

$R_{i}(t)$ : Nilai reliabilitas komponen $\mathrm{ke}-i$

\section{Index of Fit dan Goodness of Fit}

Pada penelitian ini akan digunakan Least Square Curve berdasarkan Linear Regression pada sumbu Y dengan menggunakan aplikasi Weibull 6.0 dan mengurutkan nilai $r$ (nilai Index of Fit) terbesar sampai terkecil dari keempat distribusi yang diuji. Data waktu kerusakan atau waktu pemeliharaan cocok pada distribusi yang memiliki nilai $r$ tertinggi. Berikut ini merupakan rumus $r$ dan $F\left(t_{i}\right)$ yang digunakan [4]:

$$
\begin{aligned}
& r=\frac{n \sum_{i=1}^{n} x_{i} y_{i}-\left(\sum_{i=1}^{n} x_{i}\right)\left(\sum_{i=1}^{n} y_{i}\right)}{\sqrt{\left[n \sum_{i=1}^{n} x_{i}{ }^{2}-\left(\sum_{i=1}^{n} x_{i}\right)^{2}\right]\left[n \sum_{i=1}^{n} y_{i}{ }^{2}-\left(\sum_{i=1}^{n} y_{i}\right)^{2}\right]}} \\
& F\left(t_{i}\right)=\frac{i-0.3}{n+0.4} ; 0<i \leq n
\end{aligned}
$$

Setiap distribusi memiliki definisi $x_{i}$ dan $y_{i}$ berbeda., Berikut ini merupakan definisi $x_{i}$ dan $y_{i}$ sesuai distribusi yang diuji, dimana $t_{i}$ merupakan waktu antar waktu kerusakan ke $i$ dan $0<i \leq n[4]$.

a. Distribusi Weibull

$$
\begin{aligned}
& x_{i}=\left(2 \boldsymbol{5} \boldsymbol{t}_{i}\right. \\
& y_{i}=\ln \left[\ln \left(\frac{1}{1-F\left(t_{i}\right)}\right)\right]
\end{aligned}
$$

b. Distribusi Normal

$$
\begin{aligned}
& x_{i}=t_{i}, \\
& y_{i}=\phi^{-1}\left[F\left(t_{i}\right)\right]
\end{aligned}
$$

c. Distribusi Lognormal

$$
\begin{aligned}
& x_{i}=\ln t_{i}, \\
& y_{i}=\phi^{-1}\left[F\left(t_{i}\right)\right]
\end{aligned}
$$

d. Distribusi Eksponensial

$$
\begin{gathered}
x_{i}=t_{i} \\
y_{i}=\ln \left(\frac{1}{1-F\left(t_{i}\right)}\right)
\end{gathered}
$$

Sedangkan Goodness of Fit yang digunakan adalah uji Mann untuk mengetahui data kerusakan pada pengamatan sesuai dengan distribusi weibull [4].

$H_{0}$ : Data kerusakan terdistribusi weibull

$H_{1}$ : Data kerusakan tidak terdistribusi weibull Statistik uji pada Mann sebagai:

$$
\begin{gathered}
M=\frac{k_{1} \sum_{i=k_{1}+1}^{r-1}\left[\frac{\left(\ln t_{i+1}-\ln t_{i}\right)}{M_{i}}\right]}{k_{2} \sum_{i=1}^{k_{1}}\left[\frac{\left(\ln t_{i+1}-\ln t_{i}\right)}{M_{i}}\right]} \\
M_{i}=Z_{i+1}-Z_{1} \\
Z_{i}=\ln \left[-\ln \left(1-\frac{i-0,5}{n+0,25}\right)\right] \\
k_{1}=\left\lfloor\frac{n}{2}\right\rfloor \quad ; \quad k_{2}=\left\lfloor\frac{n-1}{2}\right\rfloor \\
F_{\text {tabel }}=F_{\alpha, 2 k_{1}, 2 k_{2}}
\end{gathered}
$$

dengan,

$t_{i} \quad$ : Waktu kerusakan ke $i$

$M \quad$ : Sebuah taksiran,

$n$ : Banyaknya data,

$F_{\text {tabel }}:$ Nilai presentase distribusi F,

$\alpha \quad$ : Batas kesalahan maksimal, dalam penelitian ini peneliti menggunakan $\alpha=0,05$.

Kriteria uji kecocokan weibull adalah jika $M<F_{\text {tabel }}$ maka $H_{0}$ diterima, artinya data kerusakan terdistribusi weibull. di mana, 


\section{E. Fungsi Likelihood}

Fungsi likelihood banyak digunakan dalam menentukan estimasi, termasuk pada proses estimasi dengan metode Bayes. Informasi yang dibawa oleh pengamatan $t$ tentang $\theta$ semuanya terkandung dalam fungsi $l(\theta \mid t)$ [6]. Fungsi likelihood sebagai berikut [7]:

$$
L\left(\theta_{1}, \theta_{2} \mid t_{1}, t_{2}, \ldots, t_{n}\right)=\prod_{i=1}^{n} f(t),
$$

dengan,

$\theta_{i}:$ Parameter distribusi tertentu,

$t_{i}$ : Waktu antar waktu kerusakan ke $i$,

$f(t)$ : Fungsi padat peluang distribusi tertentu.

\section{F. Distribusi Non Informatif Prior}

Distribusi Prior Non informatif mengandung makna bahwa tidak adanya informasi distribusi probabilitas yang digunakan sebelumnya. Pendekatan Jeffrey digunakan untuk mendapatkan distribusi prior distribusi prior non informative [7]. Didefinisikan $\delta=(\theta, \varphi)$ di mana $\theta$ dan $\varphi$ merupakan parameter distribusi tertentu. Distribusi non informatif prior untuk parameter $\theta$ dengan data berukuran $n$ berdasarkan pada Informasi Fisher $(\mathrm{I}(\theta))$ sebagai berikut [8]:

$$
\begin{aligned}
& \mathrm{I}(\theta)=-n E\left[\frac{\partial^{2} \log f(t)}{\partial \theta^{2}}\right], \\
& f(\theta)=\sqrt{\mathrm{I}(\theta)},
\end{aligned}
$$

dengan,

$E\left[\frac{\partial^{2} \log f(T \mid \theta)}{\partial \theta^{2}}\right] \quad$ : Nilai ekspektasi dari $\frac{\partial^{2} \log f(T \mid \theta)}{\partial \theta^{2}}$,

$f(t)$

$\theta$

: PDF distribusi tertentu

Jika $g(\varphi)$ merupakan fungsi parameter lokasi yang diasumsikan nilai $g(\varphi)$ mendekati c, maka diperoleh distribusi prior $(\pi(\theta))$ adalah sebagai berikut:

$\pi(\theta)=f(\theta) g(\varphi)$,

dengan,

$f(\theta)$ : Nilai non-informatif prior dari parameter $\theta$,

$g(\varphi)$ : Nilai non-informatif prior dari parameter $\varphi$

\section{G. Distribusi Posterior}

Inferensi berdasarkan distribusi $\theta$ bersyarat $T$ di mana $\pi\left(\theta_{1}, \theta_{2} \mid T\right)$ merupakan simbol dari distribusi posterior dari parameter $\theta_{1}$ dan $\theta_{2}$ dapat didefinisikan dengan [6]:

$$
\pi\left(\theta_{1}, \theta_{2} \mid T\right)=\frac{L\left(\theta_{1}, \theta_{2} \mid \mathrm{T}\right) \pi(\theta)}{\iint L\left(\theta_{1}, \theta_{2} \mid \mathrm{T}\right) \pi(\theta) d \theta_{1} d \theta_{2}},
$$

\section{H. Markov Chain Monte Carlo}

Markov Chain Monte Carlo (MCMC) merupakan metode simulasi untuk membangkitkan peubah - peubah acak menggunakan rantai Markov. Teknik simulasi ini banyak digunakan dalam menyelesaikan permasalahan akibat tidak dapat disimulasi secara langsung. Hal tersebut sering terjadi dalam menyelasaikan masalah pada multiparameter maupun multidimensi khususnya pada inferensi Bayesian. Salah satu prinsip penggunaan Marcov Chain yaitu dengan Gibbs Sampler dengan menggunakan aplikasi OpenBugs [9].

\section{HASIL DAN PEMBAHASAN}

\section{A. Uji Kecocokan Data Berdasarkan Index of Fit dan Goodness of Fit}

Data yang digunakan dalam penelitian Tugas Akhir ini adalah data waktu antar waktu kerusakan ketiga pompa submersible yang disimbolkan dengan $t_{i}$ di mana $0<i \leq 82$, artinya jumlah data waktu antar waktu kerusakan ketiga pompa masing - masing sebanyak 82. Analisis kecocokan distribusi dengan data tersebut dilakukan dengan membandingkan nilai index of fit (nilai $r$ ) distribusi weibull, distribusi normal, distribusi lognormal dan distribusi eksponensial pada pompa I, II dan III.

Tabel 1.

Hasil Penghitungan Nilai $\boldsymbol{r}$ (Index of fit)

\begin{tabular}{cccccc}
\hline \hline Pump & $\begin{array}{c}\text { Dist. } \\
\text { Weibull }\end{array}$ & $\begin{array}{c}\text { Dist. } \\
\text { Normal }\end{array}$ & $\begin{array}{c}\text { Dist. } \\
\text { Log- } \\
\text { normal }\end{array}$ & $\begin{array}{c}\text { Dist. } \\
\text { Eksponensia } \\
1\end{array}$ & $\begin{array}{c}\text { Nilai } \boldsymbol{r} \\
\text { Terbesar }\end{array}$ \\
\hline I & 0.9464 & 0.8516 & 0.9410 & 0.888 & $\begin{array}{c}\text { Distribusi } \\
\text { Weibull }\end{array}$ \\
II & 0.9355 & 0.8379 & 0.8965 & 0.8511 & $\begin{array}{c}\text { Distribusi } \\
\text { Weibull }\end{array}$ \\
\hline III & 0.9297 & 0.8347 & 0.8728 & 0.8317 & $\begin{array}{c}\text { Distribusi } \\
\text { Weibull }\end{array}$ \\
\hline \hline
\end{tabular}

Berdasarkan proses penghitungan diperoleh nilai $r$ (index of fit) mengunakan (2.9) yang dapat direpresentasikan pada Tabel 4.1. Nilai $r$ tertinggi pada pompa I, pompa II dan pompa III dimiliki oleh distribusi weibull. Hal ini berarti data $t_{i}$ pompa I, pompa II dan pompa III terdistribusi weibull. Sehingga, Goodness of Fit dilakukan menggunakan uji Mann, yang mana $\alpha=0.05$ dengan hipotersis sebagai berikut:

$H_{0} \quad$ : Data $t_{i}$ pompa I, pompa II dan pompa III terdistribusi weibull

$H_{1}$ : Data $t_{i}$ pompa I, pompa II dan pompa III tidak terdistribusi weibull,

Hasil enghitungan pada Tabel 2.2 menujukkan bahwa $M<F_{\text {tabel }}$. Hal ini mengakibatkan $H_{0}$ diterima, artinya data $t_{i}$ pompa I, pompa II dan pompa III terdistribusi weibull. Jadi dapat disimpulkan bahwa untuk mencari estimasi reliabilitas pompa III digunakan model estimasi reliabilitas dengan distribusi weibull 2 parameter menggunakan metode Bayes.

Tabel 2.

Hasil Uji Mann untuk Pompa I, Pompa II dan Pompa III

\begin{tabular}{ccccc}
\hline \hline Pompa & & & $F_{\text {tabel }}$ \\
& $k_{1}$ & $k_{2}$ & $\left(F_{0.05,82,80}\right)$ & $M$ \\
\hline I & 41 & 40 & $>1.4$ & 0.779299 \\
II & 41 & 40 & $>1.4$ & 0.6009 \\
III & 41 & 40 & $>1.4$ & 0.6030 \\
\hline \hline
\end{tabular}

\section{B. Model Estimasi Reliabilitas Distribusi Weibull}

Model estimasi reliabilitas distribusi weibull didapatkan dengan melakukan transformasi dengan metode transformasi univariate dengan rumus sebagai berikut:

$$
f(y)=f\left(g^{-1}(y)\right)\left|\frac{\partial}{\partial y} g^{-1}(y)\right|
$$


Jika pada fungsi padat peluang distribusi weibull (1) dimisalkan $y=t^{\beta}$ dan $\frac{1}{\theta}=\varphi$ maka diperoleh :

$$
\begin{aligned}
& g^{-1}(y)=y^{\frac{1}{\beta}} \\
& f\left(g^{-1}(y)\right)=\beta \varphi y^{\left(1-\frac{1}{\beta}\right)} e^{-\varphi y} \\
& f(y)=\left(\varphi e^{-\varphi y}\right)=\left(\frac{1}{\theta} e^{-\frac{1}{\theta} y}\right)
\end{aligned}
$$

Setelah didapatkan hasil transformasi yaitu persamaan (3.1), terlihat bahwa persamaan tersebut berbentuk fungsi padat peluang distribusi eksponensial. Proses selanjutnya adalah mendapatkan fungsi likelihood $\left(L\left(\theta \mid y_{i}\right)\right)$ dari fungsi padat peluang eksponensial (2.1) di mana $0<i \leq n$ sebagai berikut:

$$
L\left(\theta \mid y_{i}\right)=\prod_{i=1}^{n}\left(\frac{1}{\theta} e^{-\frac{1}{\theta} y_{i}}\right)=\frac{1}{\theta^{n}} e^{-\frac{1}{\theta} \sum_{i=1}^{n} y_{i}}
$$

Distribusi prior dari distribusi eksponensial berdasarkan sehingga diperoleh Informasi Fisher sebagai berikut :

$$
\mathrm{I}(\theta)=\frac{2 n}{\theta^{2}}
$$

Maka distribsi prior dengan metode Jeffrey diperoleh :

$$
\pi(\theta)=\sqrt{\mathrm{I}(\theta)}=\frac{\sqrt{2 n}}{\theta}
$$

Tahap selanjutnya adalah menentukan distribusi posterior dengan mensubsitusikan fungsi likelihood yang telah diperoleh (3.2) dan distribusi prior (3.3) ke dalam rumus distribusi posetior (2.13) sebagai berikut.

$$
\begin{aligned}
\pi(\theta \mid T) & =\frac{\sqrt{2 n}\left(\frac{1}{\theta^{n}} e^{-\frac{1}{\theta} \sum_{i=1}^{n} y_{i}}\right)\left(\frac{1}{\theta}\right)}{\sqrt{2 n} \int_{-\infty}^{\infty}\left(\frac{1}{\theta^{n}} e^{-\frac{1}{\theta} \sum_{i=1}^{n} y_{i}}\right)\left(\frac{1}{\theta}\right) d \theta} \\
& =\frac{\left(\sum_{i=1}^{n} y_{i}\right)^{n}\left(\frac{1}{\theta^{n+1}} e^{-\frac{\sum_{i=1}^{n} y_{i}}{\theta}}\right)}{2 \Gamma(n)}
\end{aligned}
$$

Model estimasi reliabilitas diperoleh dengan mensubsitusikan distribusi posterior yang diperoleh dan fungsi reliabilitas distribusi eksponensial (2.2) terhadap rumus model estimasi reliabilitas (2.7) diperoleh :

$$
\begin{aligned}
R(t)^{*} & =E(R(t) \mid T) \\
& =\int_{-\infty}^{\infty} e^{-\frac{y}{\theta}} \frac{\left(\sum_{i=1}^{n} y_{i}\right)^{n}\left(\frac{1}{\theta^{n+1}} e^{-\frac{\sum_{i=1}^{n} y_{i}}{\theta}}\right)}{2 \Gamma(n)} d \theta \\
& =\frac{\left(\sum_{i=1}^{n} y_{i}\right)^{n}}{\left(\left(\sum_{i=1}^{n} y_{i}\right)+y\right)^{n}}
\end{aligned}
$$

Karena $y=t_{i}{ }^{\beta}$

Maka diperoleh Model estimasi Reliabilitasnya sebgai berikut:

$$
R(t)^{*}=\frac{\left(\sum_{i=1}^{n} t_{i}{ }^{\beta}\right)^{n}}{\left(\left(\sum_{i=1}^{n} t_{i}{ }^{\beta}\right)+t^{\beta}\right)^{n}}
$$

Berdasarkan model estimasi reliabilitas yang telah diperoleh, model tersebut masih mengandung parameter $\beta$ yang belum diketahui estimasi nilainya. Estimasi parameter $\beta$ ditentukan dengan metode MCMC menggunakan software OpenBugs karena distribusi posterior yang diperoleh infisible.

Hal pertama yang dilakukan dalam mengestimasi nilai parameter $\beta$ menggunakan OpenBugs adalah dengan membentuk algoritma, di mana diasumsikan distribusi prior dari $\theta \sim$ Expenensial (0.01) dan $\beta \sim \operatorname{Gamma}(0.1,0.001)$ dengan menginput data $t_{i}$ pompa I, pompa II dan pompa III.
Nilai distribusi posterior dibangkitkan dengan metode MCMC sebanyak 100.000 sehingga diperoleh hasil secara statistik seperti pada Tabel 4.6.

Tabel 3

Hasil Uji Statistik Parameter $\boldsymbol{\beta}$ Menggunakan OpenBugs

\begin{tabular}{ccccc} 
Pompa & Mean & $\begin{array}{l}\text { Standar } \\
\text { Deviasi }\end{array}$ & 5\% dari SD & MC Error \\
\hline I & 2.325 & 0.1687 & 0.0084 & 0.0022 \\
II & 2.349 & 0.1699 & 0.0085 & 0.0020 \\
III & 2.321 & 0.1697 & 0.0084 & 0.0023 \\
\hline
\end{tabular}

Berdasarkan definisinya, estimasi parameter dengan metode Bayes merupakan nilai ekspektasi dari posterior, artinya nilai parameter mendekati nilai rata - rata distribusi posteriornya [10]. Langkah selanjutnya adalah memastikan apakah nilai bangkitan posterior yang telah didapatkan bersifat konvergen. Berdasarkan Tabel 4.6 dapat diketahui bahwa nilai 0.05 dari standar deviasi distribusi posterior lebih besar disbanding Markov Chain Error maka dapat disimpulkan data bangkitan tersebut konvergen [9].

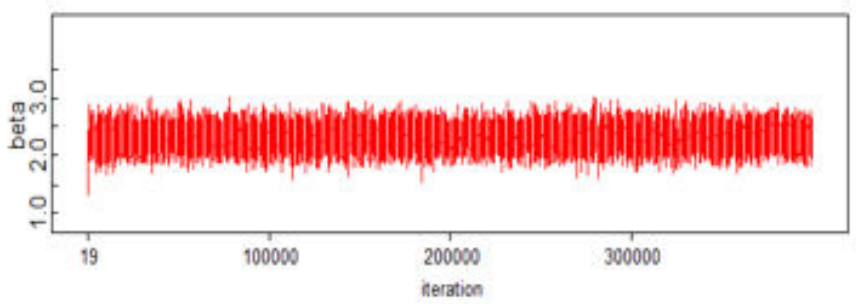

(a) History I

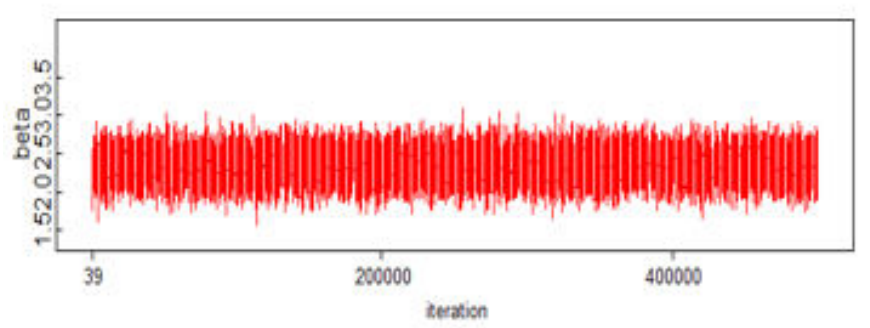

(b) History II

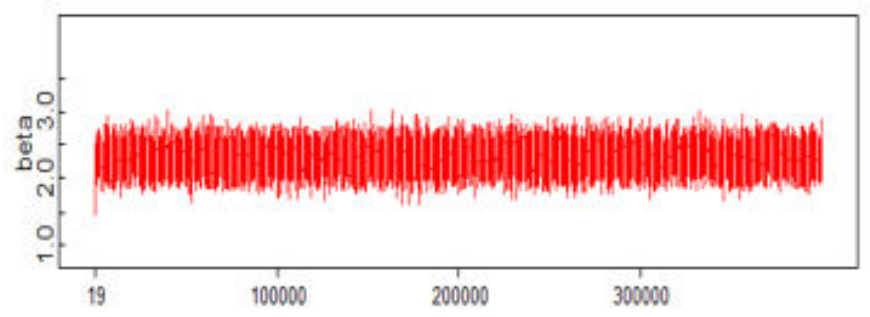

(c) History III

Gambar 1 Trace Plot Pompa I, Pompa II dan Pompa III

Selain itu kekonvergenan sebuah data dapat diuji dengan mengamati trace plot yang terdapat Gambar 3.1 Berdasrkan ketiga trace plot tersebut dapat disimpulkan bahwa data 
tersebut konvergen karena tidak ada trend atau kecenderungan dalam trace plot. Oleh karena itu, berdasarkan Tabel 3.3dapat diketahui bahwa parameter $\beta$ untuk pompa I adalah, untuk pompa II adalah dan untuk pompa III adalah. Sehingga model reliabilitas masing - masing pompa sebagai berikut :

$$
R(t)^{*}=\frac{\left(\sum_{i=1}^{n} t_{i}\right)^{n}}{\left.\left(\sum_{i=1}^{n} t_{i}{ }^{\beta}\right)+t^{\beta}\right)^{n}}
$$

di mana, $\beta=2.325$ untuk pompa I

$$
\begin{aligned}
& \beta=2.349 \text { untuk pompa II } \\
& \beta=2.321 \text { untuk pompa III }
\end{aligned}
$$

\section{Model Estimasi Relibilitas Distribusi Lognormal}

Selain distribusi weibull, distribusi lognormal banyak digunakan dalam menentukan nilai reliabilitas. Oleh karena itu dalam penelitian ini dibahas bagaimana mendapatkan model reliabilitas menggunakan distribusi lognormal dengan metode Bayes.

Berdasarkan hasil penelitian yang dilakukan Evi (2016) diperoleh estimasi parameter $\mu$ distribusi lognormal sebagai berikut [12]:

$$
\mu *=\frac{e^{-\frac{\beta}{2 \sigma^{2}}}}{2\left(\frac{2}{\beta}\right)\left(\frac{n-1}{2}\right) \Gamma\left(\frac{n-1}{2}\right)\left(\sigma^{2}\right)\left(\frac{n+1}{2}\right)}
$$

Dan distribusi posterior marginal parameter $\sigma^{2}$ :

$$
\pi\left(\sigma^{2} \mid t_{i}\right)=\frac{e^{-\frac{\beta}{2 \sigma^{2}}}}{2\left(\frac{2}{\beta}\right)^{\left(\frac{n-1}{2}\right)} \Gamma\left(\frac{n-1}{2}\right)\left(\sigma^{2}\right)^{\left(\frac{n+1}{2}\right)}}
$$

Berdasarkan persamaan (3.6) diperolehestimasi parameter $\sigma^{2}$ sebagai berikut :

$$
\begin{aligned}
& \sigma^{2} *=E\left(\sigma^{2} \mid t_{i}\right)=\int_{-\infty}^{\infty} \sigma^{2} \pi\left(\sigma^{2} \mid t_{i}\right) d \sigma^{2} \\
& =\int_{-\infty}^{\infty} \sigma^{2} \frac{e^{-\frac{\beta}{2 \sigma^{2}}}}{2\left(\frac{2}{\beta}\right)^{\left(\frac{n-1}{2}\right)} \Gamma\left(\frac{n-1}{2}\right)\left(\sigma^{2}\right)^{\left(\frac{n+1}{2}\right)}} d \sigma^{2} \\
& =\frac{\beta}{2}\left(\frac{\Gamma\left(\frac{n-3}{2}\right)}{\left(\frac{n-3}{2}\right) \Gamma\left(\frac{n-3}{2}\right)}\right) \\
& =\frac{(n-1) \sum_{i=1}^{n}\left(\ln t_{i}\right)^{2}}{n^{2}-3 n}
\end{aligned}
$$

Selanjutnya, model estimasi reliabilitas didapatkan dengan mensubsitusikan estimasi parameter (3.5) dan (3.7) ke dalam persamaan (2.6), sehingga diperoleh:

$$
\begin{aligned}
R(t) & =\phi\left(\frac{\frac{\sum_{i=1}^{n} \ln t_{i}}{n}-\ln (t)}{\frac{(n-1) \sum_{i=1}^{n}\left(\ln t_{i}\right)^{2}}{n^{2}-3 n}}\right) \\
& =\phi\left(\frac{(n-3)\left(\sum_{i=1}^{n} \ln t_{i}-n \ln (t)\right)}{(n-1) \sum_{i=1}^{n}\left(\ln t_{i}\right)^{2}}\right)
\end{aligned}
$$

\section{Hasil Estimasi Reliabilitas Pompa Submersible PDAM Kota Malang}

Langkah selanjutnya adalah menganalisis reliabilitas pompa I, pompa II dan Pompa III pada rumah pompa Wendit I PDAM Kota Malang dengan model estimasi reliabilitas yang telah diperoleh (3.4). Pada penelitian ini didapatkan estimasi reliabilitas pompa pada tanggal 15 Maret 2017. Berikut ini merupakan nilai estimasi reliabilitas pompa I yang memiliki total data $t_{i}$ sebanyak 82 :

$$
\begin{aligned}
t & =15 \text { Maret }-31 \text { Januari }\left(\text { waktu kerusakan } t_{n}\right) \\
& =43
\end{aligned}
$$

di mana,

$$
\begin{aligned}
\beta= & 2.321 \text { untuk pompa I } \\
R(t)^{*} & =\frac{\left(\sum_{i=1}^{82} t_{i}^{(2.345)}\right)^{82}}{\left(\left(\sum_{i=1}^{82} t_{i}^{(2.321)}\right)+t^{(2.321)}\right)^{82}} \\
& =\left(\frac{5550006.8713}{5550006.8713+6184.1538}\right)^{82} \\
& =0.4030
\end{aligned}
$$

Berikut ini merupakan nilai estimasi reliabilitas pompa II yang memiliki total data $t_{i}$ sebanyak 82 :

$$
\begin{aligned}
t & =15 \text { Maret }-14 \text { Februari }\left(\text { waktu kerusakan } t_{n}\right) \\
& =29
\end{aligned}
$$

di mana, $\beta=2.345$ untuk pompa II

$$
\begin{aligned}
R(t)^{*} & =\frac{\left(\sum_{i=1}^{82} t_{i}^{(2.345)}\right)^{82}}{\left(\left(\sum_{i=1}^{82} t_{i}^{(2.345)}\right)+t^{(2.345)}\right)^{82}} \\
& =\left(\frac{613178.5}{613178.5+2723.785}\right)^{82} \\
& =0.6952
\end{aligned}
$$

Berikut ini merupakan nilai estimasi reliabilitas pompa III yang memiliki total data $t_{i}$ sebanyak 82 :

$$
\begin{aligned}
t & =15 \text { Maret }-18 \text { Februari }\left(\text { waktu kerusakan } t_{n}\right) \\
& =25
\end{aligned}
$$

di mana, $\beta=2.32$ untuk pompa III

$$
\begin{aligned}
R(t)^{*} & =\frac{\left(\sum_{i=1}^{82} t_{i}^{(2.345)}\right)^{82}}{\left(\left(\sum_{i=1}^{82} t_{i}^{(2.345)}\right)+t^{(2.345)}\right)^{82}} \\
& =\left(\frac{551014.2}{551014.2+1756.381}\right)^{82} \\
& =0.7701=3
\end{aligned}
$$

Selanjutnya, adalah menentukan reliabilitas dari sistem perpompaan rumah pompa Wendit I dengan menggunakan rumus(2.8) berikut :

$$
\begin{aligned}
R_{S}(t) & =1-\left[\left(1-R_{1}(t)\right)\left(1-R_{2}(t)\right)\left(1-R_{3}(t)\right)\right] \\
& =1-[(1-0.4030)(1-0.6952)(1-0.7703)] \\
& =1-0.0417 \\
& =0.9583
\end{aligned}
$$

Maka dapat diketahui bahwa nilai reliabilitas sistem perpompaan rumah pompa Wendit I PDAM Kota Malang adalah 0.9581 .

\section{KESIMPULAN}

Berdasarakan hasil analisis dan pembahasan dapat disimpulkan bahwa model estimasi reliablitas distribusi 
weibull dengan metode Bayes secara umum adalah

$R(t)^{*}=\frac{\left(\sum_{i=1}^{n} t_{i}{ }^{\beta}\right)^{n}}{\left(\left(\sum_{i=1}^{n} t_{i}{ }^{\beta}\right)+t^{\beta}\right)^{n}}$

di mana nilai estimasi $\beta$ tergantung pada kasus yang akan ditangani. Sedangkan, model estimasi reliabilitas untuk distribusi lognormal dengan metode Bayes secara umum adalah

$$
R(t)^{*}=\phi\left(\frac{(n-3)\left(\sum_{i=1}^{n} \ln t_{i}-n \ln (t)\right)}{(n-1) \sum_{i=1}^{n}\left(\ln t_{i}\right)^{2}}\right)
$$

Model estimasi reliabilitas yang telah diperoleh diterapkan pada studi kasus dalam mendapatkan nilai reliabilitas ketiga pompa submersible pada rumah pompa Wendit I PDAM Kota Malang. Berdasarkan uji kecocokan data ketiga pompa tersebut terdistribusi weibull, maka model estimasi reliabilitas yang digunakan adalah

$$
\begin{aligned}
& R(t)^{*}=\frac{\left(\sum_{i=1}^{82} t_{i}^{\beta}\right)^{82}}{\left(\left(\sum_{i=1}^{82} t_{i} \beta\right)+t^{\beta}\right)^{82}} \\
& \text { di mana, } \beta=2.325 \text { untuk pompa I } \\
& \beta=2.349 \text { untuk pompa II } \\
& \beta=2.321 \text { untuk pompa III }
\end{aligned}
$$

Hasil perhutngan yang diperoleh berupa nilai relibilitas pada tanggal 15 Maret 2017 untuk pompa I adalah 0.4030, nilai reliabilitas pompa II adalah 0.6952 dan nilai relibilitas pompa III adalah 0.7703. Sedangkan nilai relibilitas system perpompaan pada rumah pompa Wendit I PDAM Kota Malang adalah 0.9583. Karena nilai reliabilitas system perpompaan mendekati 1 maka dapat dikatakan sistemperpompaan rumah pompa Wendit I PDAM Kota Malang sangat baik.

\section{DAFTAR PUSTAKA}

[1] R. K. Mobley, L. R. Hinggins, and D. J. Wikoff, Maintanance Engineering Handbook. New York: Mc Graw Hill, 2008.

[2] C. Sheut and Krajewski, "A Decision Model For Corrective Maintenance Management. Kansas State university,” USA, 1993.

[3] C. P. Robert, The Bayes Choice. New York: Springer-Verlag New York Inc, 1994.

[4] C. E. Ebeling, An Introduction to Reliability and Maintainability Engineering. Singapore: Mc Graw Hill, 1996.

[5] M. Rausand and A. Hoyland, System Reliability Theory, 2nd ed. USA: John Wiley \& Sons, 2004.

[6] S. . Sinha and B. K. Kale, Life Testing and Reliability Estimation. New Delhi: Wile Eastern Limited, 1980.

[7] R. E. Walpole and R. H. Myer, Ilmu Peluang dan Statistika untuk Insinyur dan Ilmuan. Bandung: ITB, 1995.

[8] R. V. Hogg and A. T. Craig, Introduction of Mathematical Statistics, 6th ed. New Jersey: Pearson Prentice Hall, 2005.

[9] I. Ntzoufras, Bayesian Modeling Using WinBugs. Canada: John Wiley \& Sons Inc, 2009.

[10]B. Puza, "Bayesian Method for Statistical Analysis," Australia, 2015. 